Revista Brasileira de Farmacognosia Brazilian Journal of Pharmacognosy 21(4): 662-667, Jul./Aug. 2011

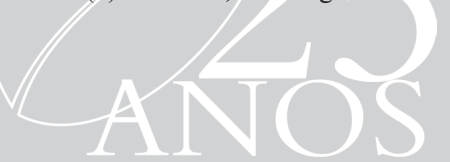

Article

Received 11 Oct 2010

Accepted 16 Feb 2011

Available online 3 Jun 2011

Keywords:

Euphorbia tirucalli

medicinal plant

type 1 cytokines

ISSN 0102-695X

doi: $10.1590 / \mathrm{S} 0102-695 \mathrm{X} 2011005000096$

\section{The crude latex of Euphorbia tirucalli modulates the cytokine response of leukocytes, especially $\mathrm{CD}^{+} \mathrm{T}$ lymphocytes}

\author{
Bethânia A. Avelar, ${ }^{1}$ Felipe J. N. Lélis, ${ }^{2}$ Renato S. Avelar, ${ }^{1}$ \\ Mathias Weber, ${ }^{3}$ Elaine M. Souza-Fagundes, ${ }^{3}$ Miriam T. P. \\ Lopes, ${ }^{2}$ Olindo A. Martins-Filho, ${ }^{1}$ Gustavo E. A. Brito-Melo ${ }^{*}, 1$
}

${ }^{1}$ Laboratorio de Imunologia, Universidade Federal do Vale do Jequitinhonha e Mucuri, Brazil,

${ }^{2}$ Laboratorio de Biomarcadores, Instituto René Rachou/Fundação Oswaldo Cruz, Brazil,

${ }^{3}$ Instituto de Ciências Biológicas, Universidade Federal de Minas Gerais, Brazil.

\begin{abstract}
The plants of the Euphorbiaceae family, especially those of the genus Euphorbia, are frequently used by Brazilian folk communities to treat a wide variety of infectious, tumoral and inflammatory illnesses. Among the species of this genus, Euphorbia tirucalli L. is widely used in some Brazilian regions, such as the Jequitinhonha River Valley. There is evidence that the latex produced by E. tirucalli has antiviral and antitumor activities, but little is known about the mechanisms involved in these effects. It is likely that the mechanism for such activities involves leukocyte activation and cytokine production. In this work, we aimed to evaluate the production of type 1 (TNF- $\alpha$ and IFN- $\gamma$ ) and type 2 (IL-4 and IL-10) cytokines by circulating leukocyte subsets submitted to brief stimulation with the crude latex of E. tirucalli. Peripheral blood leukocytes of twenty healthy subjects were submitted to $4 \mathrm{~h}$ incubation with crude E. tirucalli latex diluted in dimethylsulfoxide. After the incubation period, the cells were stained with FITC-conjugated monoclonal antibodies specific to the cell surface receptors CD4, CD8 and CD14, and to PE-conjugated monoclonal antibodies specific to the cytokines TNF- $\alpha$, IFN- $\gamma$, IL- 4 and IL-10. The acquisition and analysis of data were performed by flow cytometry. The results showed a significant increase $(p<0.05)$ in the percentage of $\mathrm{CD}^{+} \mathrm{T}$ lymphocytes positive for the type 1 cytokines TNF- $\alpha$ and IFN- $\gamma$. Neutrophils and CD8 ${ }^{+}$T lymphocytes showed a mixed profile of cytokine production, characterized by an increase in the percentage of cells expressing IFN- $\gamma$, TNF- $\alpha$, and IL-10. The data indicate a predominant type 1 cytokine response. The findings presented suggest that the effect popularly attributed to E. tirucalli usage may be attributed to its effect on the production of TNF- $\alpha$ and IFN- $\gamma$. However, the relationship between the in vitro and in vivo effects of E. tirucalli needs to be investigated.
\end{abstract}

\section{Introduction}

Plants from the Euphorbiaceae family, mainly from the Euphorbia genus, have been used by some Brazilian folk communities for the treatment of injuries, infectious illnesses, tumors and inflammatory diseases (Zhang et al., 2008; Yang et al., 2005; Uzair et al., 2009; Amirghofran et al., 2006; Fernandez-Arche et al., 2010). Regarding the high concentrations of terpenoid compounds in specific plants within this family, it is possible that some species have medicinal properties that can be exploited for therapeutic purposes (Pusztai et al., 2007; Lage et al., 2009).

Euphorbia tirucalli L., Euphorbiaceae, is commonly used in popular medicine in the Jequitinhonha River Valley, one of the poorest regions of Minas Gerais, for therapeutic purposes to treat illness and tumors (Valadares et al., 2006; Betancur-Galvis et al., 2002; Lage et al., 2009). The in vivo antitumor effect of E. tirucalli has been demonstrated (Valadares et al., 2006), although the mechanisms responsible for such effect have not been investigated.

Cytokines are important mediators in the development of efficient and adequate immunological responses against pathogens and pathological processes. Studies have shown that plants from the Euphorbia genus can alter the molecular and cellular parameters of the immune system (Amirghofran et al., 2008; Singh 
et al., 2006), suggesting that the therapeutic actions attributed to E. tirucalli could be the consequence of immune response changes evoked by the plant and not its direct action on the elements that promote the disease. In the present study, we investigated the in vitro effects of the crude latex of E. tirucalli on the production of the type 1 cytokines IFN- $\gamma$ and TNF- $\alpha$, and the type 2 cytokines IL- 4 and IL-10 by human leukocyte populations.

\section{Materials and Methods}

\section{Plant material}

Euphorbia tirucalli L. (Euphorbiaceae) latex was collected from a specimen on the campus of the Universidade Federal do Vale do Jequitinhonha e Mucuri (UFVJM), located at MGT-367 road, km-583, 5000, Diamantina, Minas Gerais, Brazil (18¹2.152’S, 4334.667'W, 1.345 $\mathrm{m}$ altitude), in January of 2009. The plant was identified by Dr. F. N. Costa, Biological Sciences Department, UFVJM. The collected samples were deposited at the UFVJM herbarium under the registration number 1897. E. tirucalli latex was collected in the morning by incision at the base of a branch. The latex was diluted immediately in dimethylsulfoxide at $10 \% \mathrm{v} / \mathrm{v}$. The quality of the solution was determined by homogeneity and the absence of precipitates.

Specific monoclonal antibodies used in flow cytometry analysis

The specific monoclonal antibodies (MoAbs) used were purchased from Pharmingen (San Diego, CA, USA), including anti-human IgG1-fluorescein isothiocyanate (FITC) clone $679 \cdot 1 \mathrm{Mc} 7$, anti-human $\mathrm{IgG}_{2 \mathrm{a}}$-phycoerythrin (PE) clone $\mathrm{U} 7 \cdot 27$, anti-human CD4-FITC clone 13 B8 $\bullet 2$, anti-human CD8-FITC clone B9・11, and anti-human CD14-FITC clone M0P9. The PE-labeled (PE) anti-human cytokine MoAbs included anti-TNF- $\alpha$ (clone MOAB11), anti-IFN- $\gamma$ (clone B27), anti-IL-4 (clone MP4-25D2), and anti-IL-10 (clone JES3-9D7).

Biological samples and short-term whole-blood culture

Leukocytes were obtained from the blood of twenty volunteers capable of blood donation with negative serology for relevant blood-borne pathogens, including HIV, hepatitis $\mathrm{C}$ virus, hepatitis $\mathrm{B}$ virus, syphilis and Chagas disease. Volunteers using corticosteroids or other immunosuppressive drugs were not considered for blood donation. Informed written consent was obtained from all participants. The study was approved by the Ethical Committee at the UFVJM, Brazil (Protocol 02/009).

Blood samples were collected in vacuum tubes containing sodium heparin (Vacutainer; Becton Dickinson, San Jose, CA, USA), and $500 \mu \mathrm{L}$ aliquots were dispensed into individual 17 × $100 \mathrm{~mm}$ polypropylene tubes (Falcon 2059, Becton Dickinson, San Jose, CA, USA). Samples were incubated for $4 \mathrm{~h}$ at $37{ }^{\circ} \mathrm{C}$ in a $5 \% \mathrm{CO}_{2}$ humidified atmosphere in the presence of $500 \mu \mathrm{L}$ of RPMI-1640 (Gibco, Grand Island, NY, USA) and Brefeldin A (BFA) (Sigma Chemical Co., St Louis, MO, USA) at a final concentration of $10 \mu \mathrm{g} / \mathrm{mL}$. The stimulation with crude E. tirucalli latex was performed by the addition of $25 \mu \mathrm{L}$ of $10 \%$ crude E. tirucalli latex diluted in DMSO (EUP group) to the cultures. A solvent control, i.e., cells treated only with DMSO $(25 \mu \mathrm{L})$, was performed in parallel (DMSO group). After solvent or latex treatment, the cultures were treated with $2 \mathrm{mM}$ ethylenediamine tetraacetic acid (EDTA) (Sigma Chemical Co.) and incubated at room temperature for $15 \mathrm{~min}$.

Flow cytometric immunostaining for surface markers and intracellular cytokines

Samples were washed with $6 \mathrm{~mL}$ of phosphatebuffered saline (PBS) containing $0.5 \%$ bovine serum albumin (BSA) and $0.1 \%$ sodium azide (Sigma). Cells were centrifuged ( $600 \times \mathrm{g}$, room temperature, $7 \mathrm{~min}$ ) and then resuspended in $\mathrm{PBS} / \mathrm{BSA} /$ sodium azide. Aliquots $(200 \mu \mathrm{L})$ were distributed into two $12 \times 75$ mm polystyrene tubes (Falcon 2052), and cells were individually stained with MoAbs directed against CD4, $\mathrm{CD} 8$, and CD14 for $30 \mathrm{~min}$ at room temperature in the dark. Stained samples were treated with $2 \mathrm{~mL}$ of FACS lysing solution (Becton Dickinson, San Jose, CA) by gentle vortexing. After re-incubation for an additional $10 \mathrm{~min}$, the samples were centrifuged $(600 \mathrm{x} g$, room temperature, $7 \mathrm{~min}$ ), and the supernatant was discarded. The pellet was dissolved in 2 mL FACS permeabilizing solution, which contains PBS/BSA/sodium azide, and $0.5 \%$ saponin (Sigma), and was incubated in the dark for $10 \mathrm{~min}$ at room temperature. After incubation, the samples were washed twice in PBS/BSA/sodium azide. Then, $20 \mu \mathrm{L}$ of PE-labeled anti-cytokine MoAb were added to cells $(20 \mu \mathrm{L})$ in a 96-well U-bottom microplate (Thomas 9383-A90) for $30 \mathrm{~min}$ at room temperature. Cells were subsequently washed with $150 \mu \mathrm{L}$ of FACS permeabilizing solution followed by $200 \mu \mathrm{L}$ of FACS buffer. Samples were then fixed in $200 \mu \mathrm{L}$ of FACS fixing solution containing $10 \mathrm{~g} / \mathrm{L}$ paraformaldehyde, $10.2 \mathrm{~g} / \mathrm{L}$ sodium cacodylate and $6.63 \mathrm{~g} / \mathrm{L}$ sodium chloride (Sigma) at $\mathrm{pH} 7.2$, stored at $4{ }^{\circ} \mathrm{C}$ in the dark, and analyzed by flow cytometry within $24 \mathrm{~h}$. 
Flow cytometry

A total of 30000 events were acquired using a FACScan flow cytometer (Becton Dickinson) correctly set up to measure forward (FSC) and side (SSC) light scattering and FITC (FL-1) and PE (FL-2) fluorescence. CellQuest $^{\mathrm{TM}}$ software was used for data acquisition and analysis. Identification of the lymphocyte subsets was performed by the dual-color immunophenotyping method using specific FITC-labeled anti-surface MoAbs and PE-labeled anti-cytokine MoAbs (BritoMelo et al., 2006).

Initially, a lymphocyte scatter gate was set up, using FSC versus SSC dot plots, followed by the identification of cytokine-positive cells using FL-1/FITC-anti-cell marker versus FL-2/PE-anticytokine dot plots. Selective analysis of neutrophils was performed by establishing a specific scatter gate using the combination of anti-cell surface antigens and laser side scatter (SSC) to discriminate and gated the neutrophils as $\mathrm{SSC}^{\text {high }} \mathrm{CD} 14^{\text {low+ }}$ cells. Following the selection of neutrophil population, the prevalence of cytokine-expressing cells was determined using quadrant statistics over FL2/anti-cytokinePE dot plots. Analysis of cytokine ${ }^{+}$monocyte was performed by double staining immunophenotyping using anti-CD14-FITC and anti-cytokine-PE labeled MoAbs. Monocytes were first selected as SSClowCD14 ${ }^{\text {hight }}$ cells, using FL1/anti-CD14-FITC versus SSC dot plots. Cytokine expression was then measured in terms of percentage of positive events within CD14 $4^{\text {high }}$ cells. All results were expressed as the percentage of cytokine-positive cells for the different gated leukocyte subpopulations analyzed in this study, selected as described above. The number of subjects displayed in the figures may differ due to methodological restrictions, including insufficient number of cells and autofluorescence interference in the flow cytometry data.

\section{Statistical analysis}

Statistical analysis was performed using analysis of variance (ANOVA) followed by Tukey's multiple comparison test using the GraphPad Prism 5 software (GraphPad Software Inc., San Diego, CA, USA). Differences were considered statistically significant when $p<0.05$.

\section{Results and Discussion}

Plants from the Euphorbiaceae family have been reportedly used as medicinal plants because of their antiviral and antitumor proprieties (Kuo et al., 2006; Yan et al., 2008; Amirghofran, 2006; Yang et al., 2005; Lage et al., 2009). However, the biological pathways involved in these processes have not been identified.

In this study, we demonstrated that the expression profiles of human peripheral blood leukocytes changed after their stimulation with crude E. tirucalli latex. As demonstrated in Table 1, lymphocytes predominantly expressed type 1 cytokines, and the IFN- $\gamma$ and TNF- $\alpha$ expression levels in this cell population were, respectively, eleven and eight times higher than those of the control group. Studies have shown that phorbol esters obtained from E. tirucalli have an inflammatory effect in rat ears (Kinghorn, 1979). The $\mathrm{CD}^{+}$and $\mathrm{CD}^{+} \mathrm{T}$ lymphocyte subsets similarly presented increased expression of TNF- $\alpha$ and IFN- $\gamma$ (Figures 1 and 2). $\mathrm{CD}^{+} \mathrm{T}$ lymphocytes are key cells involved in antiviral and antitumor immune responses. This cell population secretes cytokines that improve the recognition and cell-mediated elimination of virus-infected cells and tumor cells (Sasaki et al., 2010).

Table 1. Intracellular TNF- $\alpha$, INF- $\gamma$, IL-4, and IL-10 expression profile of circulating leukocytes after in vitro short-time stimulation with E. tirucalli latex.

\begin{tabular}{ccccc}
\hline $\begin{array}{c}\text { Peripheral } \\
\text { leukocyte } \\
\text { subsets }\end{array}$ & Cytokines & CC & DMSO & EUP \\
\hline Neutrophils & TNF- $\alpha+$ & $0.05 \pm 0.02$ & $0.05 \pm 0.03$ & $0.24 \pm 0.28^{\mathrm{a}, \mathrm{b}}$ \\
& IFN- ${ }^{+}+$ & $0.16 \pm 0.05$ & $0.15 \pm 0.08$ & $0.50 \pm 0.29^{\mathrm{a}, \mathrm{b}}$ \\
& IL-4+ & $2.26 \pm 1.18$ & $3.60 \pm 1.77$ & $7.18 \pm 3.02^{\mathrm{a}, \mathrm{b}}$ \\
& IL-10+ & $0.17 \pm 0.16$ & $0.11 \pm 0.12$ & $0.17 \pm 0.11$ \\
Monocytes & TNF- $\alpha+$ & $28.75 \pm 20.20$ & $24.29 \pm 18,42$ & $16.56 \pm 14.60$ \\
& IL-4+ & $4.27 \pm 2.40$ & $4.26 \pm 2.42$ & $6.38 \pm 3.22$ \\
& IL-10+ & $4.16 \pm 2.83$ & $4.25 \pm 3.55$ & $5.18 \pm 3.48$ \\
Lymphocytes & TNF- $\alpha+$ & $1.05 \pm 2.39$ & $0.38 \pm 0.28$ & $8.59 \pm 3.75^{\mathrm{a}, \mathrm{b}}$ \\
& IFN- $\gamma^{+}$ & $0.45 \pm 0.31$ & $0.33 \pm 0.27$ & $5.16 \pm 2.08^{\mathrm{a}, \mathrm{b}}$ \\
& IL- $4+$ & $0.56 \pm 0.27$ & $1.19 \pm 0.91^{\mathrm{a}}$ & $1.05 \pm 0.73$ \\
& IL- $10+$ & $1.72 \pm 1.79$ & $1.80 \pm 1.53$ & $1.17 \pm 0.61$ \\
\hline
\end{tabular}

Data are presented as the mean percentage \pm SD for $n=20$. CC: control group, DMSO: solvent control group, EUP: E. tirucalli latexstimulated group. Statistically significant differences are denoted by "a" for comparison with the CC group, and by "b" for comparison with the DMSO group.

The increase of type 1 cytokines mediated by plants of the Euphorbia genus was recently described. Singh et al. (2006) demonstrated that treatment with an ethanolic extract of E. hirta in allergic rats promoted an increase in the level of IFN- $\gamma$ and decreased the severity of the allergic reactions. IFN- $\gamma$ is an important type 1 cytokine because of its roles in macrophage and killer cell activation, in antigen presentation and cytotoxicity mediated by $\mathrm{CD}^{+} \mathrm{T}$ cells. Additionally, IFN- $\gamma$ induces $\mathrm{IgG}_{1}$ and $\mathrm{IgG}_{3}$ production by $\mathrm{B}$ cells. Together, these immunological elements are able to efficiently eliminate 


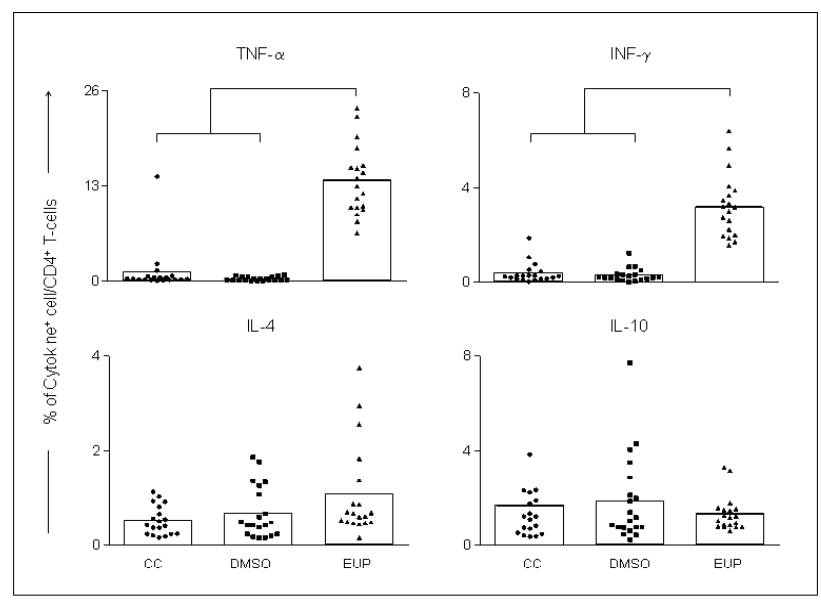

Figure 1. Intracellular TNF- $\alpha$, INF- $\gamma$, IL-4 and IL-10 expression in peripheral blood $\mathrm{CD}^{+} \mathrm{T}$ lymphocytes after shorttime stimulation in vitro with saline (CC), Dimethylsulfoxide (DMSO), and E. tirucalli latex (EUP group). The results are expressed as mean percentage + SD. Significant differences at $p<0.05$ are identified by bars between evaluated groups.

and destroy infected and tumor cells (Levy \& GarciaSastre, 2001; Duffield, 2003; Snapper \& Paul, 1987).

Euphorbia tirucalli extract diluted in saline was able to increase the survival of animals with ascitic tumors. Additionally, the hematopoiesis and spleen size of these animals returned to normal after treatment with the plant extract. However, this study neither conducted a cytokine analysis nor a detailed evaluation of the molecular mechanisms involved in the process (Valadares et al., 2006). In another report, treatment with plants from the Euphorbia genus changed the expression of multi-drug resistance (MDR) factors. These factors down-regulate the intracellular concentrations of drugs used in chemotherapy to improve tumoral resistance (Hohmann et al., 2002; Lage et al., 2009). It seems that some antitumor mechanisms are cytokine dependent primarily on IFN- $\gamma$ (Stein \& Walther, 1998). Ghiringhelli et al. (2009) demonstrated that animals injected with EL4 or EG7 tumor cells and deficient in IFN- $\gamma$ production could not be effectively treated with chemotherapy, whereas the wild-type control group responded to treatment.

The increased percentages of $\mathrm{CD}^{+} \mathrm{TNF}^{+}$and $\mathrm{CD}^{+} \mathrm{TNF}^{+} \mathrm{T}$ cells support our hypothesis that bioactive compounds from E. tirucalli improve the type 1 immune response (Figures 1 and 2). TNF- $\alpha$ is a cytokine that activates improved phagocytosis mediated by macrophages and increases the expression of adhesion molecules on endothelial cells (Wajant, 2009; Apostolaki et al., 2010). Moreover, TNF- $\alpha$ may also be an effector molecule for the apoptosis of tumor or infected cells by binding to death domains that signal apoptotic events (Screaton \& Xu, 2000).

Previous studies have demonstrated that plants

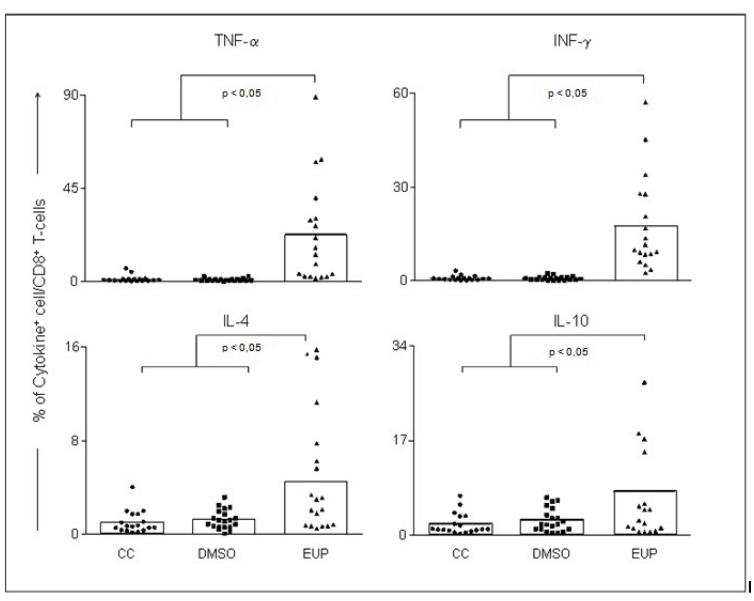

Figure 2. Intracellular TNF- $\alpha$, INF- $\gamma$, IL-4 and IL-10 expression in peripheral blood $\mathrm{CD}^{+} \mathrm{T}$ lymphocytes after short-time stimulation in vitro with saline (CC), Dimethylsulfoxide (DMSO), and E. tirucalli latex (EUP). The results are expressed as mean percentage+SD. Significant differences at $p<0.05$ are identified by bars between evaluated groups.

from the Euphorbia genus have biological activities that could be mediated by TNF- $\alpha$. For exemple, a lectin extracted from E. milii latex induced leukocyte migration (Dias-Baruffi et al., 2000), and an active fraction of the E. peplus extract induced apoptosis in melanoma cells via TNF family receptor-dependent pathways (Gillespie et al., 2004).

Neutrophils presented an increase in IL-4, IFN- $\gamma$ and TNF- $\alpha$ expression (Table 1). The increase of IL-4 expression by neutrophils, along with the increase of type 2 cytokine expression by $\mathrm{CD} 8^{+} \mathrm{T}$ lymphocytes, could modulate inflammatory responses. Type 2 cytokines inhibit the activation of inflammatory cells (Fiorentino et al., 1991). Monocytes did not contribute to the increase in cytokine production in either of the two profiles (Table 1).

Crude E. tirucalli latex extract is potentially useful in antitumor and antiviral treatments. Pre-clinical studies indicate that the plant has low toxicity in mice (Silva et al., 2007), and a considerable therapeutic index for antiviral activity (Betancur-Galvis et al., 2002). Our data suggest that the antitumor protection provided by E. tirucalli extract observed by Valadares et al. (2006) may be mediated by type 1 cytokine (TNF- $\alpha$ and INF- $\gamma$ ) expression in neutrophils and lymphocytes, particularly CD4 ${ }^{+} \mathrm{T}$ lymphocytes.

\section{Acknowledgments}

The authors thank Prof. Dr. E. Vieira for contributing to the writing of this manuscript. 


\section{References}

Amirghofran Z, Azadmehr A, Bahmani M, Javidnia K 2008. Stimulatory effects of Euphorbia cheiradenia on cell mediated immunity and humoral antibody synthesis. Iran J Immunol 5: 115-123.

Amirghofran Z, Bahmani M, Azadmehr A, Javidnia K 2006. Induction of apoptosis in leukemia cell lines by Linum persicum and Euphorbia cheiradenia. J Cancer Res Clin Oncol 132: 427-432.

Apostolaki M, Armaka M, Victoratos P, Kollias G 2010. Cellular Mechanisms of TNF Function in Models of Inflammation and Autoimmunity. Curr Dir Autoimmun 11: 1-26.

Betancur-Galvis LA, Morales GE, Forero JE, Roldan J 2002. Cytotoxic and antiviral activities of Colombian medicinal plant extracts of the Euphorbia genus. Mem Inst Oswaldo Cruz 97: 541-546.

Brito-Melo GE, Peruhype-Magalhães V, Teixeira-Carvalho A, Barbosa-Stancioli EF, Carneiro-Proietti AB, CatalanSoares B, Ribas JG, Martins-Filho OA 2007. IL-10 produced by $\mathrm{CD}^{+}$and $\mathrm{CD} 8^{+} \mathrm{T}$ cells emerge as a putative immunoregulatory mechanism to counterbalance the monocyte-derived TNF-alpha and guarantee asymptomatic clinical status during chronic HTLV-I infection. Clin Exp Immunol 147: 35-44.

Dias-Baruffi M, Sakamoto M, Rossetto S, Vozari-Hampe MM, Roque-Barreira MC 2000. Neutrophil migration and aggregation induced by euphorbin, a lectin from the latex of Euphorbia milii, var. milii. Inflamm Res 49: 732-736.

Duffield JS 2003. The inflammatory macrophage: a story of Jekyll and Hyde. Clin Sci (Lond) 104: 27-38.

Fernandez-Arche A, Saenz MT, Arroyo M, de la Puerta R, Garcia MD 2010. Topical anti-inflammatory effect of tirucallol, a triterpene isolated from Euphorbia lactea latex. Phytomedicine 17: 146-148.

Fiorentino DF, Zlotnik A, Mosmann TR, Howard M, O'Garra A 1991. IL-10 inhibits cytokine production by activated macrophages. J Immunol 147: 3815-3822.

Ghiringhelli F, Apetoh L, Tesniere A, Aymeric L, Ma Y, Ortiz C, Vermaelen K, Panaretakis T, Mignot G, Ullrich E, Perfettini JL, Schlemmer, F, Tasdemir E, Uhl M, Genin P, Civas A, Ryffel B, Kanellopoulos J, Tschopp J, Andre F, Lidereau R, McLaughlin NM, Haynes NM, Smyth, MJ, Kroemer G, Zitvogel L 2009. Activation of the NLRP3 inflammasome in dendritic cells induces IL-1betadependent adaptive immunity against tumors. Nat Med 15: 1170-1178.

Gillespie SK, Zhang XD, Hersey P 2004. Ingenol 3-angelate induces dual modes of cell death and differentially regulates tumor necrosis factor-related apoptosisinducing ligand-induced apoptosis in melanoma cells. Mol Cancer Ther 3: 1651-1658.

Hohman J, Molnar J, Redei D, Evanics F, Forgo P, Kalman A, Argay G, Szabo P 2002. Discovery and biological evaluation of a new family of potent modulators of multidrug resistance: reversal of multidrug resistance of mouse lymphoma cells by new natural jatrophane diterpenoids isolated from Euphorbia species. J Med Chem 45: 2425-2431.

Kinghorn AD 1979. Characterization of an irritant 4-deoxyphorbol diester from Euphorbia tirucalli. J Nat Prod 42: 112-115.

Kuo PL, Cho CY, Hsu YL, Lin TC, Lin CC 2006. Putranjivain A from Euphorbia jolkini inhibits proliferation of human breast adenocarcinoma MCF-7 cells via blocking cell cycle progression and inducing apoptosis. Toxicol Appl Pharmacol 213: 37-45.

Lage H, Duarte N, Coburger C, Hilgeroth A, Ferreira MJ 2009. Antitumor activity of terpenoids against classical and atypical multidrug resistant cancer cells. Phytomedicine 17: 441-448.

Levy DE, Garcia-Sastre A 2001. The virus battles: IFN induction of the antiviral state and mechanisms of viral evasion. Cytokine Growth Factor Rev 12: 143-156.

Pusztai R, Ferreira MJ, Duarte N, Engi H, Molnar J 2007. Macrocyclic lathyrane diterpenes as antitumor promoters. Anticancer Res 27: 201-205.

Sasaki K, Kohanbash G, Hoji A, Ueda R, McDonald HA, Reinhart TA, Martinson J, Lotze MT, Marincola FM, Wang E, Fujita M, Okada H 2010. miR-17-92 expression in differentiated $\mathrm{T}$ cells - implications for cancer immunotherapy. J Transl Med 8: 17 .

Screaton G, Xu XN 2000. T cell life and death signalling via TNF-receptor family members. Curr Opin Immunol 12 : 316-322.

Silva AC, de Faria DE, Borges NB, de Souza IA, Peters VM, Guerra Mde O 2007. Toxicological screening of Euphorbia tirucalli L.: developmental toxicity studies in rats. J Ethnopharmacol 110: 154-159.

Singh GD, Kaiser P, Youssouf MS, Singh S, Khajuria A, Koul A, Bani S, Kapahi BK, Satti NK, Suri KA, Johri RK 2006. Inhibition of early and late phase allergic reactions by Euphorbia hirta L. Phytother Res 20: 316-321.

Snapper CM, Paul WE 1987. Interferon-gamma and B cell stimulatory factor-1 reciprocally regulate $\mathrm{Ig}$ isotype production. Science 236: 944-947.

Stein U, Walther W 1998. Cytokine-mediated reversal of multidrug resistance. Cytotechnology 27: 271-282.

Tao HW, Hao XJ, Liu PP, Zhu WM 2008. Cytotoxic macrocyclic diterpenoids from Euphorbia helioscopia. Arch Pharm Res 31: 1547-1551.

Uzair M, Loothar BA, Choudhary BA 2009. Biological screening of Euphorbia helioscopia L. Pak J Pharm Sci 22: 184186.

Valadares MC, Carrucha SG, Accorsi W, Queiroz ML 2006. Euphorbia tirucalli L. modulates myelopoiesis and enhances the resistance of tumour-bearing mice. Int Immunopharmacol 6: 294-299.

Wang YB, Huang R, Wang HB, Jin HZ, Lou LG, Qin GW 2006. Diterpenoids from the roots of Euphorbia fischeriana. $J$ Nat Prod 69: 967-970.

Wajant H 2009. The role of TNF in cancer. Results Probl Cell Differ 49: 1-15.

Yan SS, Li Y, Wang Y, Shen SS, Gu Y, Wang HB, Qin GW, Yu Q 2008. 17-Acetoxyjolkinolide B irreversibly inhibits IkappaB kinase and induces apoptosis of tumor cells. Mol Cancer Ther 7: 1523-1532.

Yang CM, Cheng HY, Lin TC, Chiang LC, Lin CC 2005. Euphorbia thymifolia suppresses herpes simplex virus-2 infection by directly inactivating virus infectivity. Clin Exp Pharmacol Physiol 32: 346-349. 
Zhang WK, Xu JK, Zhang XQ, Yao XS, Ye WC 2008. Chemical constituents with antibacterial activity from Euphorbia sororia. Nat Prod Res 22: 353-359.

\section{*Correspondence}

Gustavo E. A. Brito-Melo

Laboratorio de Imunologia, Universidade Federal do Vale do

Jequitinhonha e Mucuri

Rodovia MGT-367, km 583, 5000, Diamantina, Minas Gerais,

Brazil

gustavomelo@ufvjm.edu.br

Tel.: +55383532 1235

Fax: +553835326000 